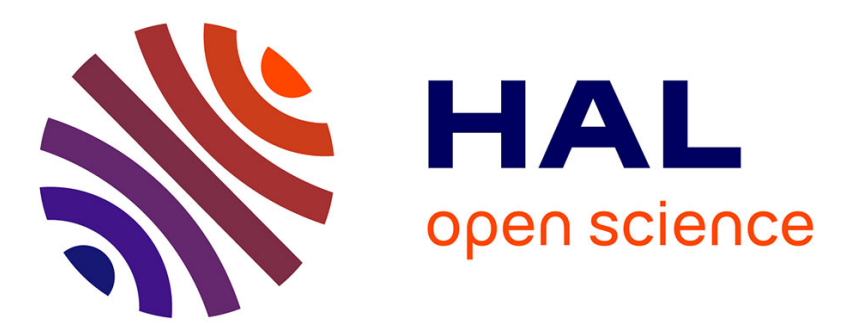

\title{
A basis for Sraffian ecological economics. A comment on Martins' "Ecosystems, strong sustainability and the classical circular economy"
}

Yoann Verger

\section{To cite this version:}

Yoann Verger. A basis for Sraffian ecological economics. A comment on Martins' "Ecosystems, strong sustainability and the classical circular economy". 2016. hal-01397937

\section{HAL Id: hal-01397937 \\ https://hal.science/hal-01397937}

Preprint submitted on 18 Nov 2016

HAL is a multi-disciplinary open access archive for the deposit and dissemination of scientific research documents, whether they are published or not. The documents may come from teaching and research institutions in France or abroad, or from public or private research centers.
L'archive ouverte pluridisciplinaire HAL, est destinée au dépôt et à la diffusion de documents scientifiques de niveau recherche, publiés ou non, émanant des établissements d'enseignement et de recherche français ou étrangers, des laboratoires publics ou privés. 


\title{
A basis for Sraffian ecological economics. A comment on Martins' "Ecosystems, strong sustainability and the classical circular economy"
}

\author{
Yoann Verger
}

National Institute for Agronomic Research, INRA - Bâtiment Bioclimatologie, route de la Ferme, 78850 Grignon

$05 / 07 / 2016$

E-mail adress: yoann.verger@grignon.inra.fr

Martins (2016) recently emphasized the role that classical economics can play in building sustainability economics. In this respect, he uses Sraffa's theory of value and Sen and Nussbaum's capability theory to support his argument. My comment focuses on the part of his article concerning Sraffa's theory, and aims to refine some of Martins claims in order to avoid misunderstandings about the possibilities offered by Sraffa's theory.

\section{The standard commodity and the universal substance}

I will start with a note from Martins where there seems to be confusion between the role of the standard commodity in Sraffa's theory and the search for a universal substance:

"Sraffa's (1960) circular conception can be more easily combined with a study of the various biophysical cycles of ecosystems when addressing supporting ecosystem services, since the cost of production of the commodities used in the economic cycle is measured in physical terms, that is, in terms of the physical inputs consumed in the process.

A crucial question concerns which is the unit used to measure those physical inputs. As Kurz and Salvadori (2010, pp. 203) note, Sraffa mentions electricity in his unpublishedwritings. But Sraffa was aware that it is difficult to find one universal substance in terms of which everything else can be measured. For this reason, Sraffa (1960) advances the idea of a standard commodity, which is a mixed 
commodity, made up of the basic commodities necessary for the reproduction of the economy in a certain proportion" (Martins, 2016).

My contention is that Sraffa solves the problem about finding a universal substance, but not in the way that Martins suggests. My argument has two steps. First, the standard commodity is just a numeraire that does not explain why commodities acquire exchange values; and second, the search for one universal substance was a search not for a numeraire but for an explanation of the commensurate measurement of commodities and of their exchange values - and Sraffa found an elegant solution to overcome this problem.

To begin with, the standard commodity was constructed by Sraffa to answer a totally different question: can we find a numeraire such that a change in the distribution would not change the value of this numeraire, so that impacts of alternative distributions of the surplus can be studied? Sraffa proves that the standard commodity owns such property, and that use of this numeraire transforms the relation between the average rate of profits and the wage per unit of labor into a strictly decreasing line. This is an important result for Sraffa, because he also shows that the maximum rate of profits (corresponding to a zero wage) can be calculated without knowing any prices, just by looking at the conditions of production. Connecting the two results, he can show that the problem of distribution of the surplus is independent of the problem of finding the prices. The levels of the wage and the rate of profits appear to be defined entirely by the social process of sharing the surplus, and not connected to any necessity from the conditions of production (the sharing of the surplus is truly a political choice).

On the other hand, the search for a universal substance is an old debate in the history of economic thought: utility plays that role in neoclassical theory, as human labor does in Marx's theory. In these theories, utility or labor are seen as an explanation of the commensurate measurement of commodities, as well as the explanation of the level of their exchange values. In ecological economics, energy was advocated as the universal substance, with the "advantage" that it is also used to produce non-manufactured resources such as natural resources. The energy theory of value could then lead to the valuation of natural resources (Gilliland, 1976; Slesser, 1977; Costanza, 1980; Costanza and Neill, 1981, 1984; Hannon, 1998; see also Georgescu-Roegen, 1975 for a strong criticism of such approach). Sraffa was also interested in the search for one "universal substance". For instance, Kurz and Salvadori (2010) show that Sraffa closely investigated Marx's labor theory of value, where human labor is the "universal substance", and rejected it:

"There appears to be no objective difference between the labour of a wage earner and that of a slave; of a slave and of a horse; of a horse and of a machine; of a machine and of an element of nature (?this does not eat). It is a purely mystical conception that attributes to human labour a special gift of determining value. Does the capitalist entrepreneur, who is the real "subject" of valuation and exchange, make a great difference whether he employs men or 
animals? Does the slave-owner?" (Piero Sraffa Papers - Wren Library, Trinity College, Cambridge - file number D3/12/9: 89 - cited in Kurz and Salvadori, 2010).

\section{Sraffa's theory of value}

My contention is that Sraffa's theory of value overcomes the problem of the search for a universal substance in quite a different way than Martins suggests. In Sraffa's theory of value, exchange value appears once we set the constraint that all commodities produced must be re-used in production so that the amount of commodities produced during the present period of production can be reproduced during the following period of production. From this constraint, exchange between present owners of the different commodities (i.e. the industry owners who sell their production on the market) becomes necessary. The ratios of these necessary exchanges are the exchange values.

It is possible that, after the necessary exchanges, a surplus remains. Therefore, some commodities that are not needed for the reproduction of present production may not have yet have an exchange value. These commodities are called non-basic. Commodities that already have an exchange value are called basic. Non-basic commodities can only acquire an exchange value if their production directly or indirectly uses basic commodities. The value of non-basic commodities is deduced from the value of basic commodities. That is why Sraffa sets the conditions that, in any system of production under study, all commodities of the system must directly or indirectly use for their production at least one common basic commodity (Sraffa, 1960, §6).

The interesting thing to note is that values are influenced by the way the surplus is distributed to the different classes of agent. The surplus is the set of commodities that are not needed to reproduce the present production (i.e. all commodities - basic or non-basic - that are over-produced in relation to the system's conditions of production). The different classes of agent are: the capitalists, who demand profits in return for the commodities advanced for production; the workers, who demand a wage in return for the labor advanced for production; and the rentiers, who ask for a rent in return for the use of the natural resources that they own. Depending on the distribution of the surplus to the different classes of agent, i.e. depending on the value of the rate of profits, wages and rents, the value of the commodities will change.

If the surplus is entirely given to the workers, all exchange values become proportional to the labor used in production, while the value of the surplus, i.e. the added value created by the system, becomes equal to the sum of the wages. Likewise, if the surplus is entirely given to the owner of the natural "energy" resource, all exchange values become proportional to the use of energy in production, while the value of the surplus is equal to the sum of the rent given to energy owners. We can thus create a labor or an energy theory of value, just by virtue of a political decision on the sharing of the surplus. But it must be clear that it would be a reversal of the logic to explain that labor or energy explain the exchange values of the commodities. 
This is why Sraffa's theory overcomes the sterile debate about the ultimate source of value, which is behind the search for one universal substance in the exchanges:

"The significance of the equations is simply this: that if a man fell from the moon on the earth, and noted the amount of things consumed in each factory [. . .] during a year he could deduce at which values the commodities must be sold, if the rate of interest must be uniform and the process of production repeated. In short, the equations show that the conditions of exchange are entirely determined by the conditions of production" (D3/12/7: A7.29.iii - cited in Garegnani, 2005).

\section{Distinction between physical world and commodities world}

This description of Sraffa's theory of value appears to me important because it helps us to understand how this theory can be used to construct sustainability economics. In this respect, another confusion may arise if Sraffa's prices are presented as sustainability prices. In this way, the following assertion from Martins is misleading:

"The prices of the basic commodities that constitute the standard commodity are those which ensure the sustainable reproduction of the system, within a standard system defined in terms of inputoutput analysis (Sraffa, 1960)" (Martins, 2016).

One important distinction must be made clear: physical exchanges that support the production of commodities are not all represented in the system of value equations. In this system, only commodities, i.e. goods or services that are exchanged on the market, and the natural resources that yield a rent, are represented. Hence, many physical relations are not represented: the extraction of raw material from nature, the disposal of waste and pollution into the environment, and non-marketed exchanges of goods and services between industries and between agents are not represented. Furthermore, the various stocks of natural resources are not accounted for.

The latter point explains why, even if Sraffa's prices represent the ratios of exchanges that ensure the reproduction of the system, they cannot ensure the physical possibility of such exchanges. It may well be that a natural resource has been depleted during the present period of production, and that its use during the next period of production is no longer possible (see also Chiodi, 1998 for a distinction between a viable system and a self-replacing system; Sraffa considers only viable systems, but not all viable systems are self-replacing). Furthermore, to call these prices sustainable is misleading, because even if reproduction is possible in the next period of production, hidden non-marketed pollution flows could alter the possibilities to continue the production process in the future. Sraffa's prices do not forecast the future, they just characterize present conditions of production (and thus present needs for reproduction). 


\section{Distinction between produced and non-produced commodities (nat- ural resources)}

Still in relation to the construction of sustainability economics, a really interesting point made by Martins is that classical economists and Sraffa have underlined the distinction between natural resources and manufactured commodities. This distinction is crucial and genuinely calls for an implementation of strong sustainability measures in order to ensure that the production process can be made sustainable. It also appears in the value system, because natural resources use no commodities or human labor as input, and can therefore acquire value only if a rent is demanded in return for their use in production:

"The distinction between rent and profits, an expression of the difference between natural resources and manufactured capital, provides a theory of value where scarcity is seen as a specific property of natural resources and studied in connection to strong sustainability" (Martins, 2016).

I may add, however, in order to avoid any confusion, that scarcity of one natural resource does not imply the appropriation of a rent. Only the conjunction between scarcity and "the appropriation of natural resources, such as more fertile lands, enable the appropriation of rent" (Martins, 2016), and there are cases where privately owned scarce natural resources do not yield any rent. Furthermore, the fact that there is a rent or not on a resource does not mean that the use of the resource is sustainably managed. It is important to focus the analysis of the sustainable management of scarcity on resources that are truly scarce, i.e. natural resources. But I do believe that a solution for their sustainable management can be found without giving an exchange value to nature, hence without using rents as a "concept for addressing the valuation of critical natural capital" (Martins, 2016). For instance, the natural resource may be managed under the regime of common property, with rules of sustainable use that do not imply exchange of money between the users.

\section{Conclusion}

In order to avoid confusion between commodities and non-commodities, and between the management of natural resources and their valuation, double accounting is required. Both the value system and the physical system related to the production of commodities must be made explicit, side by side. Both systems are of course mutually dependent, but it is important to keep them separate, as they both have specific characteristics. The value system, for instance, can produce services that will not be represented in the physical system, whereas waste, for instance, can be represented in the physical system but not in the value system. The physical conditions for sustainability can then emerge clearly, while valuation of the natural resources just appears as one of several possibilities for their sustainable management.

Do my comments contradict Martins conclusion? I think his main point was to provide a direction for research more than a precise statement on how to 
conduct this research. My comments on the goal and the method of Sraffa's theory of value, on the relation between sustainability and prices in this theory, and on the distinction between valuation of natural capital and sustainable management of this capital, aim at refining the basis of Sraffian's ecological economics. To rephrase Sraffa, if the foundation holds, the research may be attempted latter, by the writer or by someone better equipped for the task (Sraffa, 1960, Introduction).

\section{References}

Chiodi, G. (1998). On non-self-replacing states. Metroeconomica $49(1)$.

Costanza, R. (1980). Embodied energy and economic valuation. Science 210(4475), 1219-1224.

Costanza, R. and C. Neill (1981). The energy embodied in products of the biosphere, pp. 745-755. Amsterdam: Elsevier.

Costanza, R. and C. Neill (1984). Energy intensities, interdependence, and value in ecological systems: a linear programming approach. Journal of theoretical Biology 106, 41-57.

Garegnani, P. (2005). On a turning point in sraffa's theoretical and interpretative position in the late 1920s. The European Journal of the History of Economic Thought 12(3), 453-492.

Georgescu-Roegen, N. (1975). Energy and economic myths. Southern Economic Journal 41, 347-381.

Gilliland, M. W. (1975-1976). Energy analysis and public policy. Science 26 September and 2 April, 1051-1056 and 8-12.

Hannon, B. (1998). How might nature value man? Ecological Economics 25, $265-279$.

Kurz, H. D. and N. Salvadori (2010). Sraffa and the labour theory of value, pp. 189-215. London: Routledge.

Martins, N. O. (2016). Ecosystems, strong sustainability and the classical circular economy. Ecological Economics 129, 32-39.

Slesser, M. (1977). Energy analysis. Science 15 April, 259-260.

Sraffa, P. (1960). Production of Commodities by Means of Commodities. Bombay: K. K. Vora, Vora \& Co. 